\title{
Detrital protein contributes to oyster nutrition and growth in the Damariscotta estuary, Maine, USA
}

\author{
Cheyenne M. Adams ${ }^{1, *}$, Lawrence M. Mayer ${ }^{1}$, Paul Rawson ${ }^{2,4}$, Damian C. Brady ${ }^{1,4}$, \\ Carter Newell ${ }^{3,4}$
}

\author{
${ }^{1}$ Darling Marine Center, School of Marine Sciences, University of Maine, Walpole, ME 04573, USA \\ ${ }^{2}$ School of Marine Sciences, University of Maine, Orono, ME 04469, USA \\ ${ }^{3}$ Maine Shellfish Research and Development, Bucksport, ME 04416, USA \\ ${ }^{4}$ Aquaculture Research Institute, University of Maine, Orono, ME 04469; USA
}

\begin{abstract}
The expansion of oyster aquaculture relies on identifying and utilizing estuarine conditions that enable the economical production of a filter-feeding species. Detrital complexes may provide nutrition to oysters between beneficial phytoplankton blooms. The upper Damariscotta estuary is the most successful aquaculture site in Maine for eastern oysters Crassostrea virginica. To examine the impact of labile detrital protein detected in this estuary on oyster growth, we monitored enzymatically hydrolysable amino acids (EHAA, labile protein), chlorophyll a (chl a) and particulate organic matter (POM) biweekly, along with continuous monitoring of temperature, turbidity, and chl a by a Land/Ocean Biogeochemical Observatory (LOBO) buoy. Oyster feeding and growth were measured biweekly in the field and in a controlled laboratory experiment to assess responses to detrital proteins. Phytoplankton alone provided insufficient nutrition for field oysters based on measured POM absorption rate, suggesting a role for additional organics such as detritus in oyster nutrition. Oysters readily absorbed phytodetritus under laboratory conditions and cleared phytodetritus with high efficiency under field conditions. Bioavailable EHAA in the field was nearly completely absorbed by oysters, unlike POM, and seasonal EHAA concentrations correlate well with field growth rates. These indications of protein limitation on oyster growth are not explained by phytoplankton, which cannot account for all EHAA, and are consistent with seasonally abundant, labile detrital protein and observed phytodetritus. Detrital protein influence on this species implies that EHAA measurements can improve aquaculture site selection, help determine nutritional carrying capacity of estuaries, and help explain clarification of water columns by these filter feeders.
\end{abstract}

KEY WORDS: Oyster - Detritus · Protein - Bioavailable - EHAA · Crassostrea virginica . Aquaculture $\cdot$ Feeding

\section{INTRODUCTION}

Shellfish aquaculture presents a significant opportunity to meet increased global food demand and minimize pressure on diminishing wild fish stocks and arable land (Costa-Pierce 2010). In Maine (USA), aquaculture of the eastern oyster Crassostrea virginica has expanded 6-fold from 2011 to 2018, with recent landings worth US $\$ 8.1$ million. Maine's $5600 \mathrm{~km}$ of shore-

\footnotetext{
*Corresponding author: cheyenne.adams@maine.edu
}

line provides high economic and ecological potential for oyster aquaculture, though nearly $70 \%$ of the current statewide harvest takes place in the Damariscotta estuary (Maine Department of Marine Resources 2018). Expansion of oyster aquaculture into other regional estuaries requires a better understanding of suitable culture habitats.

The quantity and quality of seston available as nutrition to filter-feeding oysters, over which farmers

(C) The authors 2019. Open Access under Creative Commons by Attribution Licence. Use, distribution and reproduction are unrestricted. Authors and original publication must be credited. 
exert no control, can strongly affect yield. The concentration of particulate organic matter/carbon (POM/C) is typically used to assess the bulk nutritional resources available to bivalves, while the nutritional quality of seston is often estimated by the concentration of phytoplankton-derived pigment chlorophyll a (chl a) (e.g. Hawkins et al. 1986, 1996, 1998, 2013b, Soletchnik et al. 1996, Barillé et al. 1997, Suplicy et al. 2003, Galimany et al. 2017).

However, nitrogenous compounds can often limit growth in secondary producers such as oysters (Bowen et al. 1995). Both laboratory (e.g. Romberger \& Epifanio 1981, Hawkins \& Bayne 1991, Ibarrola et al. 1996, 2000, Brown et al. 1997) and field studies (e.g. Grémare et al. 1997, Bayne 2009) suggest the supply of protein in the diet can be nutritionally limiting for bivalves. For example, the cockle Cerastoderma edule absorbs nitrogen more efficiently than total organic matter (Urrutia et al. 1996) and absorbs proteins more efficiently than lipids (Ibarrola et al. 2000), implying preference for protein-rich food. In bivalves more generally, growth rates typically increase with increasing protein availability up to a maximum ration (Hawkins \& Bayne 1991, Kreeger \& Langdon 1993, Wikfors et al. 1996, Chi et al. 2010).

Feeding in C. virginica responds flexibly to environmental variability (Nelson 1960, Langdon \& Newell 1990, Ward \& Shumway 2004, Galimany et al. 2017) and can have important ecosystem effects, such as increased water clarity (Newell 2004). Oysters can identify, select and take advantage of a range of particulates, including both phytoplankton rich in chl $a$ and other potentially nutritious organic particles, such as detritus (e.g. Palmer \& Williams 1980, Newell \& Jordan 1983, MacDonald \& Ward 1994, Hawkins et al. 2013b). Detritus is broadly defined as dead and decomposing organic matter derived from local production and/or exogenous inputs (Roman 1983). A clear quantification metric for detritus has been elusive due to varied sources, size, and biochemical nature (Cebrian \& Lartigue 2004). Detritus has been characterized as all non-chlorophyll associated, or non-phytoplanktonic, POM (Hager et al. 1984, Hawkins et al. 2013a) and can therefore include autotrophic necromass, heterotrophic biomass and necromass, and complex aggregates containing each. Oysters can selectively ingest phytoplankton (Ward et al. 1998, Ward \& Shumway 2004), but detritus often dominates POM in estuarine systems (Steinberg \& Saba 2008) and may offer significant nutrition (Levinton et al. 2002, Byron et al. 2011), especially after nitrogen enrichment of some detritus types during decay (Newell 1982,
Paerl 1984, Biddanda \& Pomeroy 1988, Alber \& Valiela 1996).

Hawkins et al. (2013a) observed that, at times, live phytoplankton provided only a small fraction of the diet of $C$. gigas and the remainder (up to $90 \%$ of absorbed energy) was detritus as defined above. Attached (i.e. detrital) and free bacteria alone can provide up to $27 \%$ of total nitrogen requirements of C. virginica (Langdon \& Newell 1990). Though some detrital components are refractory and provide insignificant nutrition (Newell \& Langdon 1986), bacterial colonization of particles can convert refractory detritus into more bioavailable compounds (Crosby et al. 1990). For example, oysters absorb only $3 \%$ of the total nitrogen in salt-marsh detritus but absorb $57 \%$ of nitrogen from cellulolytic bacteria colonizing that detritus (Crosby et al. 1990). Thus, some concentration-based growth models have found that POM (Ren \& Ross 2001) and chl a (Bourlès et al. 2009) levels fail to accurately predict oyster growth rates and perhaps need more food quality information.

Nitrogenous compounds, measured as total nitrogen or biopolymer concentrations, are only partially bioavailable (Mayer et al. 1995, Dauwe et al. 1999, Hawkins et al. 2013b). Therefore, it is important to assess the fraction of total protein in naturally occurring seston that is labile, i.e. available for absorption by heterotrophs (Hawkins et al. 2013b, Bayne 2017). Mayer et al. (1995) developed a biomimetic assay for enzymatically hydrolyzable amino acids (EHAA) to estimate this relatively labile fraction of protein. Studies measuring in situ EHAA concentration have observed positive correlations with deposit-feeding bivalve growth and macroinvertebrate species diversity (Grémare et al. 1997, Bonifácio et al. 2014). A study examining seasonal variation of EHAA in the seston of the Damariscotta estuary found the EHAA consisted of varying combinations of live phytoplankton and phytoplankton-derived detritus, or phytodetritus (Laursen et al. 1996). Phytodetritus is particularly nutritious relative to other detrital particles and may be able to provide an ephemeral but significant amount of nutrition to filter feeders, especially between phytoplankton blooms (Lopez \& Levinton 2011).

Here, we address the hypothesis that bioavailable, detrital protein in the Damariscotta estuary contributes significant nutrition to farmed $C$. virginica and thus is an important parameter to consider when expanding bivalve culture into new estuarine systems. We test this hypothesis by coupling measures of food quantity and quality to bioassays of oyster feeding and growth. 


\section{MATERIALS AND METHODS}

\subsection{Research strategy}

We employed laboratory and field experiments, along with an extended seasonal field study correlating Crassostrea virginica feeding and growth with variation in environmental parameters. A laboratory experiment addressed if phytodetritus is nutritious and if oysters can absorb it for growth (Section 2.2). A field experiment was designed to test whether oysters clear natural phytodetrital material from the water column (Section 2.3). Finally, field monitoring of seston and oyster feeding and growth throughout the growing season was used to test if oysters absorb and grow on detrital protein in situ (Section 2.4).

\subsection{Laboratory algal rot}

In a laboratory-based phytodetritus experiment, we subjected a dense diatom culture to decay by a naturally occurring microbial community to mimic one pathway of detritus formation and monitored the feeding response of oysters to this detritus. Thalassiosira weissflogii was grown to $\sim 1 \times 10^{6}$ cells $\mathrm{ml}^{-1}$ and gently centrifuged into a paste. The concentrate was homogenized, separated into $50 \mathrm{ml}$ aliquots, and frozen at $-80^{\circ} \mathrm{C}$. Aliquots were thawed at room temperature and resuspended to $2 \mathrm{~g}$ dry weight $\mathrm{l}^{-1}$ in $15 \mathrm{l}$ of natural estuarine seawater filtered at $1 \mu \mathrm{m}$ and UV-sterilized. Microscopic examination confirmed that the resuspended algal cells were intact. A $1 \mathrm{ml}$ sample of seawater from the Damariscotta estuary was filtered to $1 \mu \mathrm{m}$ without UV sterilization and used as a microbial inoculum. This algal rot suspension was left undisturbed at $19.5^{\circ} \mathrm{C}$ in the dark to inhibit algal growth and monitored daily. At Days 0, 2,5 , and 12 , varying volumes of the algal rot suspension were removed and added to a $600 \mathrm{l}$ oyster feed tank to achieve an average concentration of $2.7 \pm$ $0.1 \mathrm{mg} \mathrm{POM} \mathrm{l}^{-1}$. Varying volumes of algal rot suspension were added to the feed tank to account for carbon loss from bacterial respiration as the algal rot proceeded in order to maintain a constant POM ration in the feed tank on each experimental day. Powdered kaolinite was added to a concentration of $5.8 \pm 0.4 \mathrm{mg} \mathrm{l}^{-1}$ as a conservative tracer for use in the biodeposition method (described below). Dosage of $<6.5 \mathrm{mg} \mathrm{l}^{-1}$ was designed to minimize adverse effects of kaolinite on particle selectivity, as observed at higher concentrations (Loosanoff \& Tommers 1948, Loosanoff 1962, Urban \& Kirchman 1992), and any such effects are expected to be consistent across all stages of algal decay. Concentrations of POM and particulate inorganic matter (PIM) in the feed tank were similar to conditions observed in the Damariscotta estuary throughout the season.

Suspended particulate matter was filtered in triplicate from the feed tank onto Whatman GF/F filters. POM was measured gravimetrically as in Hawkins et al. (2013b). Chl a and pheopigments (pigment degradation products) were measured on a Turner 10-AU fluorometer using standard acetone extraction methods (Holm-Hansen \& Riemann 1978) to quantify both live and senescing phytoplankton. Particulate organic carbon and nitrogen (POC/N) were measured on a Perkin-Elmer CHNS/O 2400B analyzer. Bacterial and algal cells were enumerated by flow cytometry (J.J. MacIsaac Facility for Aquatic Cytometry, Bigelow Laboratory for Ocean Sciences, JJMFAC/BLOS), using the nucleic acid stain SYBR Green I to label bacterial cells and red fluorescence (>670 nm) of photosynthetic pigments to identify algal cells. Enzymatically hydrolyzable amino acids (EHAA) were measured using the protocol of Mayer et al. (1995) as adapted for seston filters (Laursen et al. 1996). This biomimetic approach uses a nonspecific proteinase to digest proteinaceous material in the samples and quantifies the resulting production of absorbable amino acids and oligopeptides. To assess food quality via elemental compositions, EHAA concentrations were converted to carbon and nitrogen equivalents based on average protein composition $(1 / 2$ carbon and $1 / 6$ nitrogen by weight; Mayer et al. 1995). All equipment was precleaned with either RBS-35 or $10 \%$ hydrochloric acid.

The feeding and absorption response of oysters $C$. virginica to changes in chemical composition of algal rot was assessed by the biodeposition method. Hawkins et al. (2013b) and Iglesias et al. (1998) provide a complete discussion of the method and calculations, but an overview is included here (Table 1). Market size oysters of 61 to $78 \mathrm{~mm}$ were maintained at $19.5^{\circ} \mathrm{C}$ and fed live T. weissflogii for $2 \mathrm{wk}$ prior to and between experiments. A subsample of 10 individual oysters were depurated via starvation for $48 \mathrm{~h}$ and then placed in $400 \mathrm{ml}$ flow-through feeding chambers and provided with $200 \mathrm{ml} \mathrm{min}^{-1}$ of algal rot ration from the feed tank (slightly greater water flow than the field feeding experiment and equal to water flow in the seasonal study, both described below). Two empty control chambers were monitored simultaneously in each run to correct for settlement of particulates. Oysters were fed for $6 \mathrm{~h}$ on Days 0, 2, 5, and 12 of the algal rot process, after which true feces and pseudofeces were collected separately for analysis. 
Table 1. Selected feeding behaviors with acronyms and calculations. Refer to Hawkins et al. (2013b) for a comprehensive list and explanation of calculations used in the biodeposition method. POM refers to particulate organic matter, and PIM refers to particulate inorganic matter, both as $\mathrm{mg} \mathrm{l}^{-1}$

\begin{tabular}{|c|c|c|c|}
\hline Parameter & Acronym & Units & Calculation \\
\hline Chlorophyll-rich organic matter & SELORG & $\mathrm{mg} \mathrm{l}^{-1}$ & {$[(\mathrm{chl} a \times 50) / 0.38] / 1000$} \\
\hline Remaining organic matter & REMORG & $\mathrm{mg} \mathrm{l}^{-1}$ & POM - SELORG \\
\hline Clearance rate & $\mathrm{CR}$ & $1 \mathrm{~h}^{-1}$ & ( $\mathrm{mg} \mathrm{h}^{-1}$ inorganic matter egested in feces and pseudofeces / PIM) \\
\hline Ingested organic matter & & $\mathrm{mg} \mathrm{h}^{-1}$ & $(\mathrm{CR} \times \mathrm{POM})-\left(\mathrm{mg} \mathrm{h}^{-1}\right.$ organic matter egested in pseudofeces $)$ \\
\hline Absorption rate & $\mathrm{AR}$ & $\mathrm{mg} \mathrm{h}^{-1}$ & ( $\mathrm{mg} \mathrm{h}^{-1}$ ingested organic matter $)-\left(\mathrm{mg} \mathrm{h}^{-1}\right.$ organic matter egested in feces) \\
\hline SELORG fraction of diet & & & $(\mathrm{SELORG} \times \mathrm{CR}) / \mathrm{AR}$ \\
\hline REMORG fraction of diet & & & {$[\mathrm{AR}-(\mathrm{SELORG} \times \mathrm{CR})] / \mathrm{AR}$} \\
\hline
\end{tabular}

POM and PIM concentrations from water samples were compared to POM and PIM in biodeposits to calculate absorption rate (AR), clearance rate $(\mathrm{CR})$, and absorption efficiency (AE). The $6 \mathrm{~h}$ feeding period did not allow for the production of sufficient biodeposits for EHAA or chl a analyses on this material. Feeding rates were standardized per gram dry weight ( $g D W$ ) of soft tissue. Following each experiment, soft tissue was dissected from each experimental oyster, dried at $60^{\circ} \mathrm{C}$ for $2 \mathrm{~d}$, and weighed. Inactive oysters were removed from statistical analyses, leaving final sample sizes of 6 to 9 oysters for each experimental day.

\subsection{Field feeding experiment}

A field-based feeding experiment tested phytodetrital clearance by oysters under field conditions. Water samples were analyzed using a FlowCam (Fluid Imaging Technologies, Scarborough, ME) at JJMFAC/BLOS to identify and quantify fluorescent seston particles, including phytodetritus, using a $4 \times$ objective, $300 \mu \mathrm{m}$ flow cell, and $532 \mathrm{~nm}$ (green) laser on fluorescence trigger mode for particles $>20 \mu \mathrm{m}$. Images were analyzed in Visual Spreadsheet Software (Fluid Imaging Technologies), and biovolume estimates were determined following the method of Sieracki et al. (1989), where particle boundary points were found using the connected-component labeling algorithm of Chang et al. (2004), as implemented in Burger \& Berge (2008) and described by Cetiníc et al. (2015). Phytodetritus was identified as auto-fluorescing but amorphous and otherwise unidentifiable particles. Diatom cell carbon was calculated from derived biovolumes using the algorithms of Menden-Deuer \& Lessard (2000), but the heterogeneous nature of phytodetritus makes estimation of mass from volume impossible.

The flow-through feeding chambers, described above for the algal rot experiment, were deployed in situ at the Pemaquid Oyster Company lease site in the upper Damariscotta River (hereafter Damariscotta estuary). The upper Damariscotta estuary is a drowned valley with very low freshwater input $\left(1\right.$ to $\left.3 \mathrm{~m}^{3} \mathrm{~s}^{-1}\right)$ resulting in typical summer salinities of 25 to 32 (McAlice 1977, Mayer et al. 1996). Due to extensive shallows (4-10 m), water temperatures reach seasonal temperature peaks of 20 to $24^{\circ} \mathrm{C}$ (McAlice 1977), which is highly conducive to eastern oyster growth (Ingersoll 1881, Maine Department of Marine Resources 2018).

Market-size oysters (61-114 mm) held in surface cages throughout the study duration (therefore acclimated to natural field conditions) were supplied with seawater pumped from $1 \mathrm{~m}$ depth flowing at $150 \mathrm{ml}$ $\min ^{-1}$ and acclimated to each chamber for a $12.5 \mathrm{~h}$, night-time tidal cycle. Water flow was lower than in the algal rot experiment (Section 2.2) to ensure that oysters removed sufficient particles for accurate FlowCam water sample analysis. The presence of biodeposits confirmed that oysters were actively feeding. After the $12.5 \mathrm{~h}$ acclimation, and while oysters were actively feeding, outflow water samples were collected and particle concentration was compared between oyster feeding chambers and control chambers to estimate particle removal, or clearance, by the oysters as water flowed through the chambers. Only $>20 \mu \mathrm{m}$ diatoms and phytodetritus were included in this analysis. The experiment was conducted twice, 11 July and $23 \mathrm{Au}-$ gust 2016, with pooled samples from 7 oysters. The decision to pool water and biodeposit samples for each experimental day $(\mathrm{n}=1)$ was driven by project funding constraints and precluded statistical analysis.

\subsection{Seasonal field study}

\subsubsection{Environmental conditions and oyster diet}

The field study examined how oyster feeding and growth responded to seasonal variations in environmental conditions at the Pemaquid Oyster Company 
lease site. A Land/Ocean Biogeochemistry Observatory (LOBO; SeaBird Scientific) buoy nearby $(1.6 \mathrm{~km})$ measured temperature, turbidity (optical backscattering), and chlorophyll- $\alpha$ (fluorescence) at $1.5 \mathrm{~m}$ depth. These continuous measurements allowed integration at various time scales to develop a baseline oyster growth model. We also collected biweekly water samples in triplicate at the LOBO mooring from $1 \mathrm{~m}$ depth, filtered onto Whatman GF/F filters, and measured POM, EHAA, and pigments as above (Section 2.2). Seasonal variation in EHAA:chl a ratios were used to assess the relative contributions from live algal and detrital proteins in the seston. Assuming that an EHAA:chl a ratio of $40 \mathrm{~g}^{\text {EHAA }} \mathrm{g}^{-1} \mathrm{chl}$ a represents average phytoplankton (Laursen et al. 1996), EHAA:chl a ratios > $40 \mathrm{~g} \mathrm{EHAA}^{-1} \mathrm{chl} a$ indicate EHAA abundance in excess of what can be attributed to phytoplankton and thus may be detrital protein.

We assessed the response of oysters to environmental changes by measuring feeding and growth rates biweekly from 31 May to 11 October 2016. Feeding rates were measured on the same day water samples were collected at the LOBO buoy, indicating instantaneous biological response to environmental conditions at the time of sampling. Growth rates were measured on alternate weeks and therefore integrate the physiological effects of environmental variation over the preceding week.

For feeding behavior assessment, the flow-through chambers were deployed in situ as in the field feeding experiment (Section 2.3), but with 50 to $98 \mathrm{~mm}$

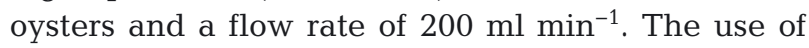
smaller oysters and faster flow rates prevented $>50 \%$ reduction of seston in chambers that might have affected oyster feeding. The flow rate differences between the field feeding experiment and seasonal field study prevent direct comparisons of the results between them. An ISCO 3700 Sampler collected ambient water every $30 \mathrm{~min}$ during deployment to obtain a composite water sample representative of the $12.5 \mathrm{~h}$ tidal cycle. This composite water sample was analyzed for POM, PIM, and EHAA and compared with the same measurements of the biodeposits from each chamber to characterize individual oyster feeding behavior as in Section 2.2. For feeding rate calculations that include chl $a$, we used the LOBO buoy chl a measurements averaged over each $12.5 \mathrm{~h}$ deployment period. Buoy fluorometer data were adjusted with a regression against extracted chl $a$ values obtained from biweekly water samples, excluding times of photoquenching from the buoy data, leading to a correction factor of 1.40. Insufficient biodeposits were recovered for chl a analysis, but EHAA analysis was possible on 2 occasions to enable estimation of EHAA absorption efficiency. Feeding rates were standardized per $\mathrm{g}$ DW of soft tissue with the dry weights of each oyster obtained as above (Section 2.2). Inactive oysters were removed from statistical analysis; final sample size ranged from 6 to 10 oysters for each sampling date.

The organic matter diet of oysters in the field feeding experiment was partitioned into nutritional pools as per Hawkins et al. (2013a,b). The potential contribution of algal biomass was calculated as the chlorophyll-rich organic matter that is preferentially selected by oysters (SELORG); the potential non-living and/or non-algal organic matter contribution to oyster diet was calculated as all remaining organic matter (REMORG), including, but not limited to, detrital material (Table 1). The fraction of the diet from SELORG is calculated as the maximum potential fraction assuming $100 \%$ absorption efficiency, and the fraction of the diet from REMORG is calculated as the remaining organic absorption requirements based on measured POM absorption rate. By assuming the maximum potential fraction of diet from SELORG, we minimize the potential fraction of diet from REMORG. The assumption that all phytoplankton organics are absorbed, although unlikely (see Navarro et al. 2016 for an infaunal bivalve), would be expected to produce the most conservative assessment of the role of detritus in oyster diets. For these calculations, we used a C:chl a ratio (wt/wt) of 50, which is a typical value for phytoplankton (Welschmeyer \& Lorenzen 1984, Hawkins et al. 2013a). Hawkins et al. (2013b) used a C:chl a conversion factor of 12 to quantify SELORG, which they defined as chl a-rich organic matter known to be filtered and ingested preferentially. This factor of 12 is consistent with values measured in fast-growing and thus high-quality algal monocultures (Taylor et al. 1997) and also ensured that SELORG did not exceed the measured total organics on any occasion (Hawkins et al. 2013b). Our use of a ratio of 50 leads to a more conservative estimate of detrital contribution to oyster diet.

\subsubsection{Oyster growth rates}

Specific growth rates of individual oysters were calculated from biweekly shell height measurements. Specific growth rate is a log ratio that normalizes to initial oyster size at each time interval and is often used to assess environmental impacts on bivalve success (e.g. Clausen \& Riisgård 1996, 
Mills 2000, Chi et al. 2010, Karayücel et al. 2010, Malkin et al. 2012, Riisgård et al. 2012). Initially, 120 spat-sized oysters ( $25 \mathrm{~mm}$ shell height) were individually marked by gluing numbered tags (Bee Works, Queen Marking Kit) to the shell and were deployed in May 2016 in 2 plastic mesh oyster culture bags on surface nursery lines at the Pemaquid Oyster Company lease site. Oysters were acclimated to field conditions for $2 \mathrm{wk}$ before initial shell height measurements were taken to reduce artifacts from handling. Mortality and tag loss throughout the season resulted in a final sample size of 63 individual oysters in October 2016.

\subsection{Statistical analyses}

Differences among mean values of water quality and feeding behaviors in the laboratory algal rot and seasonal field study were examined with 1-way ANOVA. When the experiment-wise results were significant ( $p<0.05$ ), we used Tukey HSD for posthoc pairwise comparisons of individual means. In some cases (e.g. direct comparisons between mean values for the absorption efficiencies of EHAA and POM in the seasonal field study), we used a 2-way Student's $t$-test with significance determined at $\alpha<0.05$. Specific growth rates were correlated with the discrete samples of water quality parameters measured 7 to $10 \mathrm{~d}$ prior to each shell size measurement, except one occasion (16 June) when growth rates were compared to averaged water quality data from the previous 2 samplings (31 May and 14 June). The timeframe of 7 to $10 \mathrm{~d}$ reflected in this correlation is on the order of the residence time of water in the system (McAlice 1977), thus roughly indicating how long the oysters may be exposed to similar food conditions.

Single parameter explanations of individual oyster growth rates (63 individual growth rates calculated for 8 to 10 time points) were analyzed by nonparametric rank correlation coefficients (Spearman's rho, $\rho)$. Residual plots (predicted values vs. residuals) from all correlations were randomly distributed (slope $=0, p>0.05$ ). To assess the combined effects of multiple parameters on variability in growth rates, two stepwise multiple linear regression models were constructed in MATLAB ${ }^{\circledR}$ (MathWorks, Natick, MA). Models used moving averages of LOBOderived water quality measurements ranging from 1 to $7 \mathrm{~d}$ prior to growth sampling and were constrained to $\leq 3$ independent variables. Our baseline model used only the high-density data set from the LOBO buoy; this choice allowed basic environmen- tal variables that could be averaged across different time periods preceding the growth measurement and are easily transferable to other locations for future comparison. Possible independent variables included temperature, $\mathrm{chl} a$, turbidity, and the ratio of chl a to turbidity (chl a:Turb). A follow-up model included biweekly data for EHAA, POM, and pigments to test for improvement in model fit. All possible combinations of independent variables were generated, but only the best fit models from each model run are presented here. The Akaike information criterion (AIC) was calculated for each model and models with the lowest AIC score are presented. AIC balances goodness-of-fit and model overfitting by including a penalty for each new covariate added (Burnham \& Anderson 2002). In this way, we present only models where covariates significantly improved model fit. In each model, positive and negative correlations are indicated by the sign of the regression coefficient for each term (+ and -, respectively), and residual plots (predicted values vs. residuals) from presented models were randomly distributed (slope $=0, \mathrm{p}>0.05$ ).

\section{RESULTS}

\subsection{Laboratory algal rot}

As the algal rot progressed, chl a concentrations decreased significantly from $3.3 \pm 0.1 \mathrm{\mu g} \mathrm{l}^{-1}$ on Day 0 to $<0.29 \pm 0.1 \mu \mathrm{g} \mathrm{l}^{-1}$ on Days 5 and 12 (1-way ANOVA, $F_{3,11}=68.33, \mathrm{p}<0.0001$ ), while pheopigment concentrations increased significantly from $0.0 \pm 0.0 \mu \mathrm{g} \mathrm{l}^{-1}$ on Day 0 to $>3.9 \pm 0.1 \mu \mathrm{g} \mathrm{l}^{-1}$ on Days 5 and 12 (Fig. $1 \mathrm{~A}_{;}$ 1 -way ANOVA, $\left.F_{3,11}=124.4, \mathrm{p}<0.0001\right)$. The decline in algal cell numbers from $4.0 \times 10^{9}$ to $1.7 \times 10^{9} \mathrm{l}^{-1}$ (Fig. 1B) was less pronounced than the decline in chl $a$, suggesting intracellular pigment decay. Bacterial cell numbers increased nearly an order of magnitude from $2.9 \times 10^{10}$ to $1.3 \times 10^{11} \mathrm{l}^{-1}$ (Fig. 1B), indicating their role in algal decomposition. The reduction in algal cell number and increase in bacterial abundance as the rot progressed were both lower than observed in previous algal rot experiments (L. M. Mayer unpubl. data). Even so, as algal biomass decayed, it was converted partially into bacterial biomass and partially into algal necromass to form a product here termed 'bacteriogenic phytodetritus'. The POC concentration per volume of algal rot suspension decreased by 31 \% from Day 0 to Day 12 due to bacterial respiration (data not shown), but the fraction of remaining organic carbon that was in EHAA 

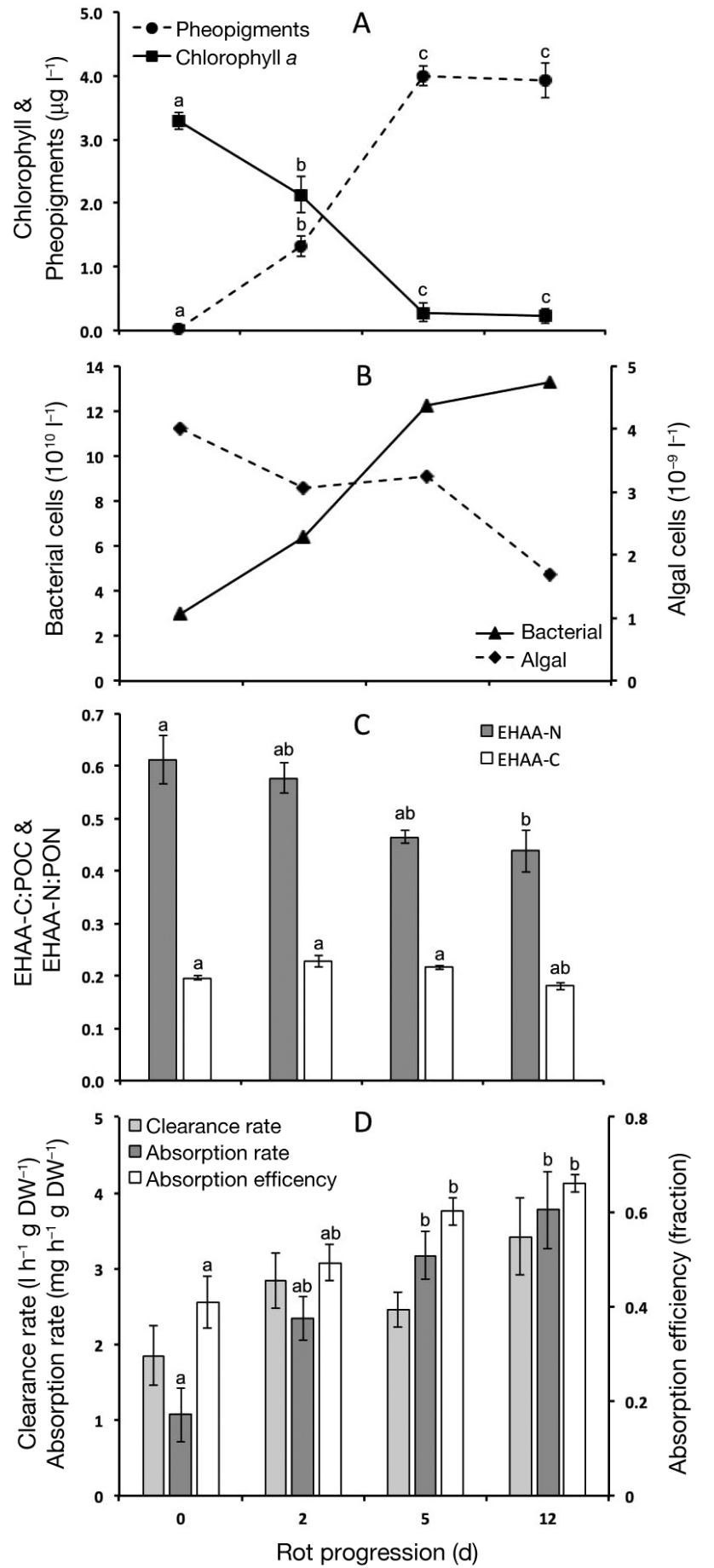

Fig. 1. Variation in food quality and corresponding animal feeding response during the algal rot experiment. (A) Replacement of chlorophyll by phaeopigments during algal decay; (B) cell counts of original Thalassiosira weissflogii cells and successional bacteria; (C) food quality assessed as the ratios of enzymatically hydrolyzable amino acids nitrogen content (EHAA-N) to particulate organic nitrogen (PON) and the EHAA carbon content (EHAAC) to particulate organic carbon (POC). (D) Absorption rates (AR), clearance rates (CR), and absorption efficiency (AE) of oysters fed on particulates at different stages of decay. Letters indicate significant difference $(\mathrm{p}<0.05)$ based on a Tukey HSD test. Points and error bars represent means \pm 1 standard error form (EHAA-C:POC) remained relatively constant (Fig. $1 C_{i} 1$-way ANOVA, $F_{3,10}=4.94, p=0.053$ ). In contrast, the fraction of organic nitrogen in EHAA form (EHAA-N:PON) declined by $>33 \%$ (1-way ANOVA, $F_{3,10}=6.53, \mathrm{p}<0.05$ ) due to relatively constant PON coupled with decreasing EHAA concentrations.

Crassostrea virginica fed on particulates at all stages of decay. Clearance rate (CR) varied from 1.8 to $3.3 \mathrm{l} \mathrm{h}^{-1} \mathrm{gDW}^{-1}$, but there was no clear pattern to the variation in day-specific means (1-way ANOVA, $\left.F_{3,29}=2.92, \mathrm{p}>0.05\right)$. In contrast, increases in both AR and $\mathrm{AE}$ of POM were significant. Absorption rate increased from $1.1 \pm 0.4$ to $3.7 \pm 0.5 \mathrm{mg} \mathrm{h}^{-1} \mathrm{gDW}^{-1}$ (1-way ANOVA, $\left.F_{3,29}=9.63, \mathrm{p}<0.001\right)$. and absorption efficiency increased from $0.41 \pm 0.05$ to $0.66 \pm 0.02$ (1-way ANOVA, $\left.F_{3,29}=7.56, \mathrm{p}<0.001\right)$ as the algal rot progressed (Fig. 1D).

\subsection{Field feeding experiment}

Oysters in the field experiment fed on both phytoplankton and phytodetritus. Phytodetritus comprised 13 to $23 \%$ of total seston in the control chamber outflow and was largely absent from the outflow of chambers holding oysters on both experimental dates (Table 2). Oysters removed $3.5 \times 10^{7}$ and $1.3 \times 10^{8}$ $\mu^{3} \mathrm{l}^{-1}$ of phytodetritus on 11 July and 23 August, respectively, as water flowed through each chamber. The density and composition of phytodetritus varies widely, preventing accurate volumetric quantification and direct comparisons between phytodetritus and phytoplankton (diatoms) biovolumes. Nevertheless, we compared the phytodetrital biovolume removed from the oyster chambers to the initial biovolume (assuming similar nature of inflow and outflow phytodetrital particles) to calculate the percent reduction and compare this to the percent reduction of diatoms. Based on this assumption, oysters cleared phytodetritus with greater efficiency than diatoms, especially on 23 August (Table 2).

\subsection{Seasonal field study}

\subsubsection{Environmental conditions and oyster diet}

Water temperatures ranged from 10.8 to $24.3^{\circ} \mathrm{C}$, peaking in July (Fig. 2A). Turbidity (Fig. 2B) varied with spring/neap tidal periodicity, likely due to sediment resuspension on spring tides in the shallow upper estuary as indicated by a positive correlation between turbidity and tidal current velocity (Spear- 
Table 2. Diatoms and phytodetritus (>20 $\mu \mathrm{m}$, autofluorescing) in Crassostrea virginica field feeding experiment. Empty control chambers were compared to the oyster feeding chambers to calculate the change in biovolume and percent reduction of each particle type

\begin{tabular}{|c|c|c|c|c|c|}
\hline \multirow[t]{2}{*}{ Date } & \multirow{2}{*}{ Particle } & \multicolumn{3}{|c|}{- Biovolume $\left(\mu \mathrm{m}^{3} \mathrm{l}^{-1}\right)$} & \multirow{2}{*}{$\begin{array}{c}\text { Reduction } \\
(\%)\end{array}$} \\
\hline & & Control & Oyster & Change & \\
\hline \multirow{2}{*}{ 11-Jul } & Diatoms & $6.9 \times 10^{7}$ & $9.8 \times 10^{6}$ & $-5.9 \times 10^{7}$ & 85.8 \\
\hline & Phytodetritus & $3.6 \times 10^{7}$ & $1.0 \times 10^{6}$ & $-3.5 \times 10^{7}$ & 97.2 \\
\hline \multirow{2}{*}{ 23-Aug } & Diatoms & $4.8 \times 10^{8}$ & $3.3 \times 10^{8}$ & $-1.5 \times 10^{8}$ & 31.0 \\
\hline & Phytodetritus & $1.9 \times 10^{8}$ & $6.0 \times 10^{7}$ & $-1.3 \times 10^{8}$ & 68.0 \\
\hline
\end{tabular}

man's non-parametric correlation, $\rho=$ 0.13, $\mathrm{p}<0.0001)$. Additionally, the largest spring tide of the sampling season (5 July) coincided with the highest PIM:POM ratio. Extracted chl a measurements varied from $2.5 \pm 0.0 \mu \mathrm{g} \mathrm{l}^{-1}$ in May to $9.8 \pm 0.3 \mu \mathrm{g} \mathrm{l}^{-1}$ during a September diatom bloom (Fig. 2C). The pattern of seasonal variation in EHAA concentrations was similar to that of extracted chl $a$, and the EHAA:chl $a$ ratio varied over the course of the

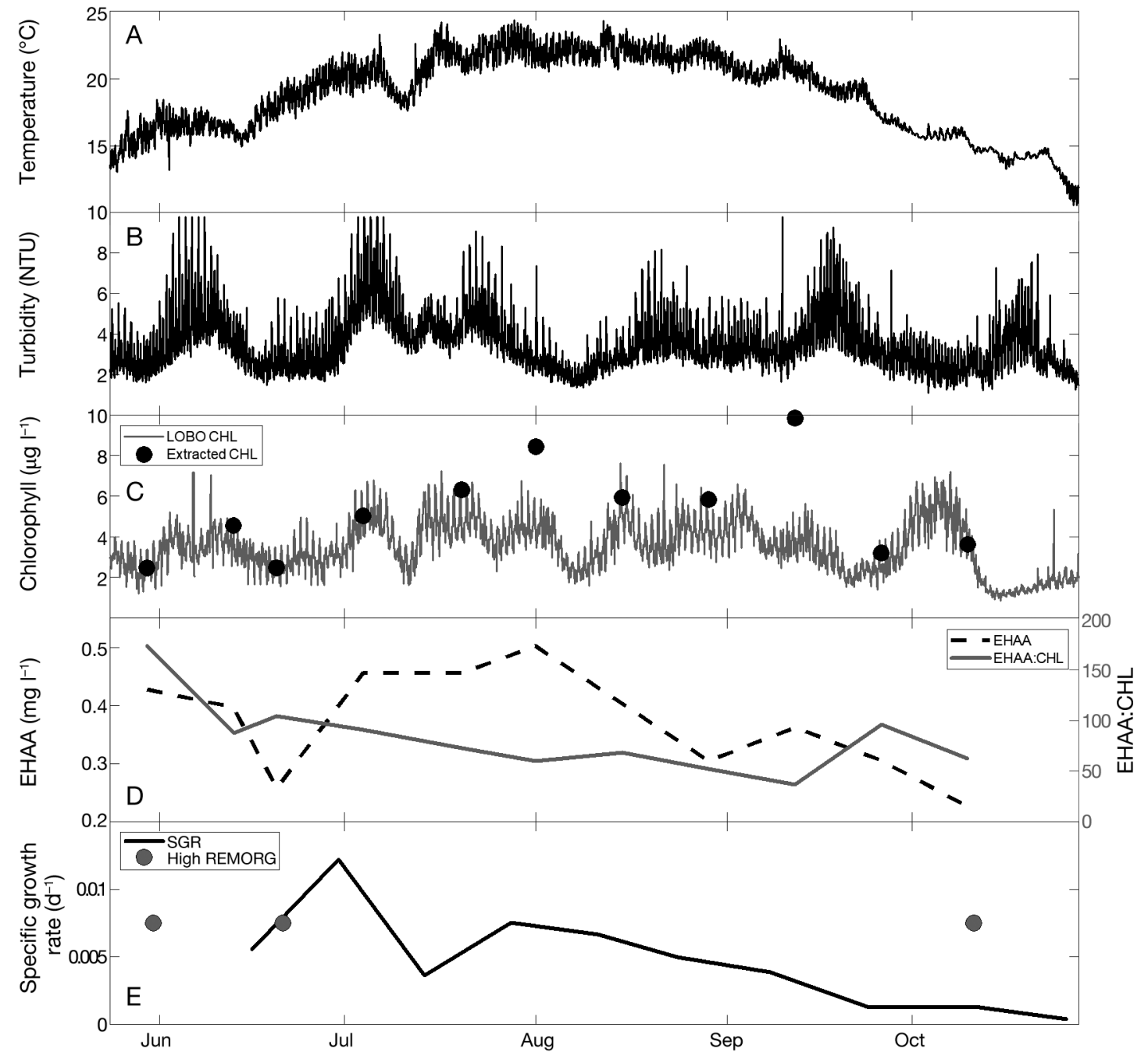

Fig. 2. Water quality and biological response in the upper Damariscotta estuary throughout the season. (A) Seasonal variation in temperature from the Land/Ocean Biogeochemical Observatory (LOBO) buoy. (B) Seasonal turbidity from the LOBO buoy varies with spring-neap tidal periodicity. (C) Chlorophyll a $(\mathrm{chl}$ a) data were obtained via both acetone extractions in the lab and from the LOBO buoy. Extracted values are sometimes higher than buoy values due to error from in situ fluorometry, such as photoquenching and biofouling. (D) EHAA concentration and ratio of enzymatically hydrolyzable amino acids (EHAA) to extracted chl $a$, estimating the relative phytoplanktonic and detrital contributions to the seston. E) Three dates of high non-phytoplanktonic, remaining organic matter (REMORG) abundance plotted with the biological response of oyster specific growth rate (SGR); note that SGR integrates feeding in the prior 1-2 wk, so that the first SGR data point was influenced by the first 


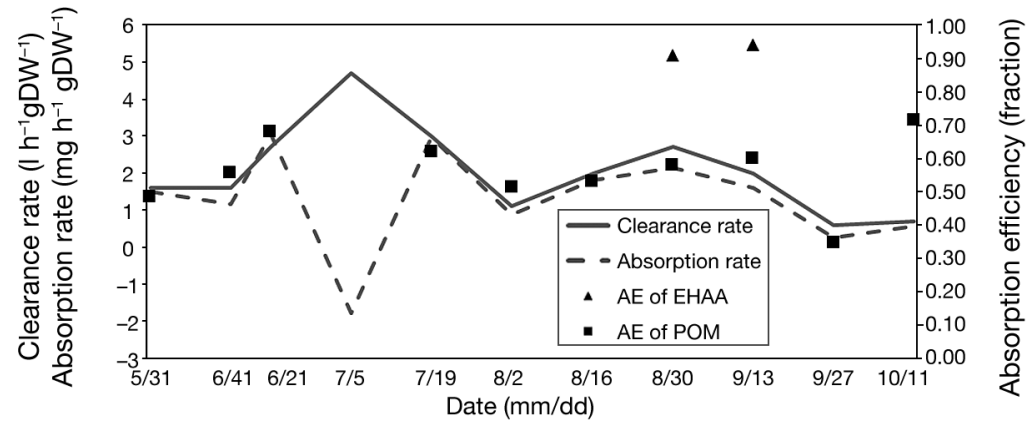

Fig. 3. Oyster feeding behavior throughout the growing season. Clearance rate was highest on 5 July during a sediment resuspension event. Absorption rate was negative on this date, which made the calculation of absorption efficiency impossible. Although absorption efficiency of EHAA was only calculated on 2 dates, it was significantly higher than absorption efficiency of POM on both dates $(\mathrm{p}<0.001)$

season from $174 \mathrm{~g}$ EHAA $\mathrm{g}^{-1} \mathrm{chl} a$ in May to

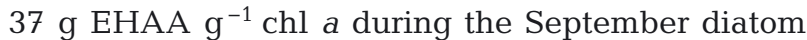
bloom (Fig. 2D). Based on an EHAA:chl a value of 40 g EHAA $g$ chl a for average phytoplankton (Laursen et al. 1996), only $23 \%$ of EHAA can be attributed to algae in the spring, suggesting that the majority of labile protein at that time was non-algal and/or nonliving (i.e. detrital). In contrast, the EHAA:chl $a$

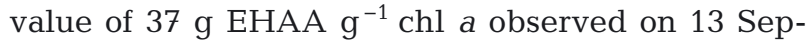
tember indicates that essentially all labile protein at this time point was associated with a phytoplankton bloom.

Oysters cleared particles from the water at rates that loosely scaled with seasonal temperatures, ranging from $0.6 \pm 0.1$ to $4.7 \pm 0.6 \mathrm{l} \mathrm{h}^{-1} \mathrm{gDW}^{-1}$ (Fig. 3). Clearance rate in C. virginica is strongly influenced by temperature, especially at the northern end of its range (Loosanoff 1958, Carriker \& Gaffney 1996, Comeau 2014), but a notable exception occurred on 5 July when CR was unseasonably high (4.7 \pm $0.6 \mathrm{lh}^{-1} \mathrm{gDW}^{-1}$ ) coincident with the largest spring tides and sediment resuspension when PIM:POM was $\sim 8$.

Absorption rate of $\mathrm{POM}$ ranged seasonally from $-1.8 \pm 1.1$ to $3.0 \pm 0.4 \mathrm{mg} \mathrm{h}^{-1} \mathrm{gDW}^{-1}$ (Fig. 3) and correlates negatively with PIM:POM ratio (Fig. 4 ; best fit model was a linear regression, $\mathrm{p}<0.05, \mathrm{R}^{2}=0.37$ ). Absorption rate was negative on only one occasion, which was the sediment resuspension event on 5 July. Absorption efficiency of POM ranged from 0.35 \pm 0.09 to $0.71 \pm 0.06$ (average $=0.58 \pm 0.02$ ) with no clear seasonal trend (Fig. 3). On 2 occasions when sufficient biodeposits were recovered for EHAA analysis, AE of EHAA was compared to AE of POM ( $\mathrm{n}=4$ oysters on each occasion; Fig. 3). On both dates, AE of EHAA $(0.91 \pm 0.03$ and $0.94 \pm 0.02)$ was significantly higher (2-way Student's $t$-test, $\mathrm{p}<0.001$ ) than AE of POM $(0.67 \pm 0.01$ and $0.64 \pm 0.01)$. AE of EHAA on both dates is also higher than a previously reported $\mathrm{AE}$ of $\mathrm{chl}$ a $(0.82 \pm 0.03$; Soletchnik et al. 1996). Thus, essentially all EHAAs were absorbed by the oysters (i.e. were bioavailable) as predicted by the biomimetic chemical assay. However, some proteins absorbed by the oysters may not be detectable by the EHAA assay.

The AR of POM represents consumption of all organic material and consists of contributions from algal (SELORG) and other (REMORG) organic material. Usually, the chlorophyll-rich SELORG material in seston was sufficiently abundant to be the dominant fraction of oyster diets, ranging from $0.44 \pm 0.01$ in June to $1.00 \pm$ 0.00 during the September diatom bloom. Assuming all available SELORG was absorbed by oysters, the minimum REMORG fractional contribution to oyster diet was higher than SELORG on 2 occasions, 21 June $(0.56 \pm 0.01)$ and 11 October $(0.53 \pm 0.03)$ and constituted a substantial proportion of the total diet on 31 May $(0.37 \pm 0.04)$. Unseasonably high specific growth rates were observed around each of these 3 dates of relatively high REMORG contribution to oyster diets (Fig. 2E). Because separation of diet into fractions requires a positive value for $A R$, the negative estimate for AR on 5 July made dietary fraction calculations impossible for this date. Diet fractionation based on nitrogen equivalents shows similar patterns to this carbon-based fractionation.

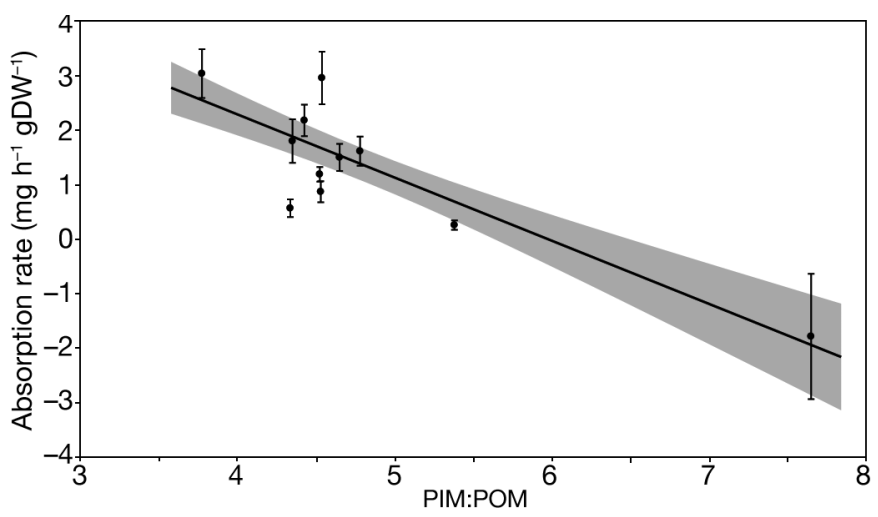

Fig. 4. Linear regression (regression line and 95\% slope intervals) between organic absorption rate by oysters and seston PIM:POM. The ratio between particulate inorganic matter (PIM) and particulate organic matter (POM) matter indicates dilution of organic food particles with inorganic material, such as sediment from the tidal resuspension event. Observed variation in PIM:POM negatively affects oyster absorption rate $\left(p<0.05, R^{2}=0.37\right)$. The relationship is still significant when the highest PIM:POM value is removed from analysis. Circles: means, error bars: \pm 1 standard error, and $\mathrm{n}=10$ for each sampling date 


\subsubsection{Oyster growth rates}

From May to October 2016, average oyster shell height doubled from $36.6 \pm 0.6$ to $73.8 \pm 0.8 \mathrm{~mm}$. Specific growth rates were generally higher from May to July and peaked at $1.2 \times 10^{-2} \pm 0.06 \times 10^{-2} \mathrm{~d}^{-1}$ on 30 June, after which they slowly declined to $0.04 \times 10^{-2} \pm$ $0.01 \times 10^{-2} \mathrm{~d}^{-1}$ on 26 October as water temperature dropped (Fig. 2E). Linear growth rates exhibited this same trend. An unseasonably low growth rate of 0.36 $\times 10^{-2} \pm 0.04 \times 10^{-2} \mathrm{~d}^{-1}$ on 14 July corresponds with the tidal sediment resuspension event on 5 July that also resulted in negative AR (Fig. 4).

Specific growth rates generally responded positively to EHAA concentrations, except for one notable outlier on 30 Jun - the highest growth rate of the season (EHAA of $0.26 \mathrm{mg} \mathrm{l}^{-1}$; Fig. 5). This correlation is highly significant (Spearman's non-parametric correlation, $\rho=0.83, p=0.006$ ) when the outlier (outside $95 \%$ confidence density ellipse for bivariate outlier analysis) is removed from analysis. Temperature also showed significant positive correlation with specific growth rates (Spearman's non-parametric correlation, $\rho=0.66, p=0.0384$ ). No outliers were found in the temperature correlation dataset and all data points were used in the correlation.

It should be noted that correlations between specific growth rate and total particulate matter, POM, and chl a (extracted and buoy data $1 \mathrm{~d}$ average as per multiple linear regression below), which are commonly used food parameters in filter-feeding bivalve growth models, were by themselves not statistically

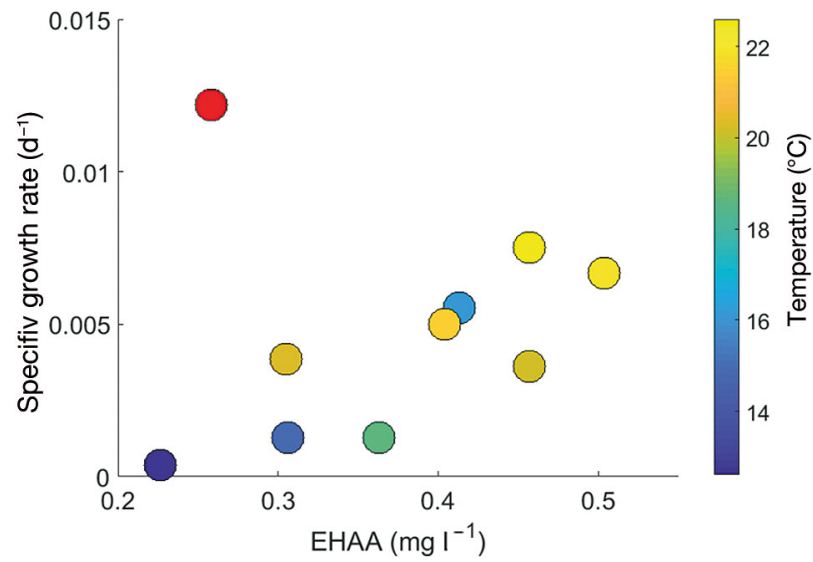

Fig. 5. Correlation between oyster specific growth rate and enzymatically hydrolyzable amino acid (EHAA) concentrations. Specific growth rates correlate positively with seasonal EHAA concentrations, but there is 1 statistical outlier present. The outlier is outside a $95 \%$ confidence density ellipse for bivariate analysis and is shown in red. Spearman's nonparametric correlation coefficient $(\rho=0.83)$ is significant $(p=0.006)$ when the outlier is removed from analysis significant in this study (Spearman's non-parametric correlation, $\mathrm{p}>0.05$ ).

The baseline best fit model (and lowest AIC) created to predict oyster growth using independent variables included $1 \mathrm{~d}$ averages of temperature and chl a:Turb $\left(\mathrm{R}^{2}=0.84, \mathrm{p}<0.01\right.$; Table 3, Fig. 6A). The 30 June data point was removed from analysis because the Mahalanobis distance-based on the distance of the datum from the multivariate meanexceeded the upper control limit (Sikder et al. 2014). Among all other parameters measured in this study, adding biweekly EHAA concentrations to the baseline model gave the best improvement on the baseline fit (achieving $\mathrm{R}^{2}=0.91, \mathrm{p}<0.0001$; Table 3, Fig. 6B) when the 30 June outlier was again removed from analysis. In this augmented model, $1 \mathrm{~d}$ averages of temperature $(+)$ and chl a:Turb (+) remained important terms that contributed significantly to the regression relationship.

\section{DISCUSSION}

The importance of detrital protein to Crassostrea virginica productivity in the Damariscotta estuary was assessed through mechanistic (feeding) and correlative (growth) studies. While evidence for the contribution of this food source to eastern oyster feeding and growth in this study is indirect, the 3 aspects of this study consistently support its importance.

\subsection{Indicators of detrital utilization}

Oysters efficiently absorbed the bacteriogenic phytodetritus complexes under laboratory conditions, which strongly indicates that such complexes are bioavailable and readily utilized by oysters. However, it is worth noting that low AE of POM observed at Day 0, prior to decay, is at odds with high AE values (0.72-0.90) typically reported for shellfish feeding on phytoplankton cultures (Romberger \& Epifanio 1981, Alber \& Valiela 1996) and is similar to AE of POM values observed in the seasonal field study. The low AE at Day 0 may be at least partially due to processing of live algal culture into a concentrated suspension for decomposition. Also, because biodeposits were collected immediately after a $6 \mathrm{~h}$ feeding period without allowing oysters to completely depurate, observed increases in AR and AE over time may reflect increases in gut retention times (GRT). We consider this explanation unlikely because ingestion rates increased as the rot progressed, and higher 
Table 3. Two multiple linear regression models to predict specific growth rate of oysters based on temperature (Temp), chlorophyll a (chl a), turbidity (Turb), chl a:Turb ratio, enzymatically hydrolyzable amino acids (EHAA), particulate organic matter (POM), and pigments. Both model runs were constrained to 3 terms and using 1 to $7 \mathrm{~d}$ moving averages of LOBO buoy variables where applicable (indicated by the number after the variable name in best fit equations). One outlier (Mahalanobis distance $>$ upper control limit) was removed from both models (30 June specific growth rate [SGR] measurements)

\begin{tabular}{|c|c|c|c|c|}
\hline Model & Optional variables & Best fit equation & $\mathrm{R}^{2}$ & $\mathrm{p}$ \\
\hline Baseline & 1-7 d Temp, chl a, Turb, chl a:Turb & $\begin{array}{l}\mathrm{SGR}=-0.011+\left(2.5 \times 10^{-4} \mathrm{Temp} 1\right) \\
+\left(9.7 \times 10^{-3} \mathrm{chl} a: \text { Turb } 1\right)\end{array}$ & 0.84 & 0.01 \\
\hline EHAA & $\begin{array}{l}\text { 1-7 d Temp, chl } a \text {, Turb, chl a:Turb, EHAA, } \\
\text { POM, pigments }\end{array}$ & $\begin{array}{l}\text { SGR }=-0.011+\left(6.9 \times 10^{-5} \text { Temp1 }\right) \\
+\left(8.8 \times 10^{-3} \text { chl } a: \text { Turb1 }\right)+\left(1.1 \times 10^{-2} \text { EHAA }\right)\end{array}$ & 0.91 & 0.0001 \\
\hline
\end{tabular}

ingestion rates are often associated with shorter GRT (Navarro et al. 1992, 2009). Ingestion rates were calculated with measurements of pseudofeces (which are unaffected by digestive processes) and PIM of feces. While the production of feces is affected by changes in GRT, increasing GRT over the short time period of this study would likely decrease the total mass of PIM in feces (although the ratio PIM:POM may increase) and underestimate ingestion rate. Our estimates are therefore the minimum possible ingestion rates and increases over time suggest that GRT is more likely to have decreased than increased.

As the algal rot progressed, we observed statistically significant increases in both absorption rate and absorption efficiency. Total nitrogen was conserved relative to total carbon and EHAA as microbial respiration proceeded and phytoplankton cells decayed, implying conversion of EHAA nitrogen to other nitrogenous compounds (Mayer et al. 2009). Bacteria and other heterotrophs can enrich the nutritive value of decayed material relative to fresh particles via processes such as bacterial assimilation of dissolved and inorganic nitrogen (Paerl 1984, Biddanda \& Pomeroy 1988, Rice \& Hanson 1988, Sanzone et al. 2001) into particles of an accessible size for oysters (Ward \& Shumway 2004). It is possible that our CR and AR measurements include small nutritious particles captured on the Whatman filters that are not normally filtered by oysters (Ward \& Shumway 2004), but at least the free-living bacteria that grew during the rot process likely made up only a small fraction of available phytodetritus biomass. Previous studies (Newell et al. 1981) and our own unpublished data have shown that bacterial biomass makes up a small mass fraction of phytodetritus in such algal rot experiments. Our findings of increasing $\mathrm{AR}$ and $\mathrm{AE}$, as live algal cells evolved into bacteriogenic phytodetritus, imply that similar detrital complexes under natural conditions could serve as a valuable nutritional resource.
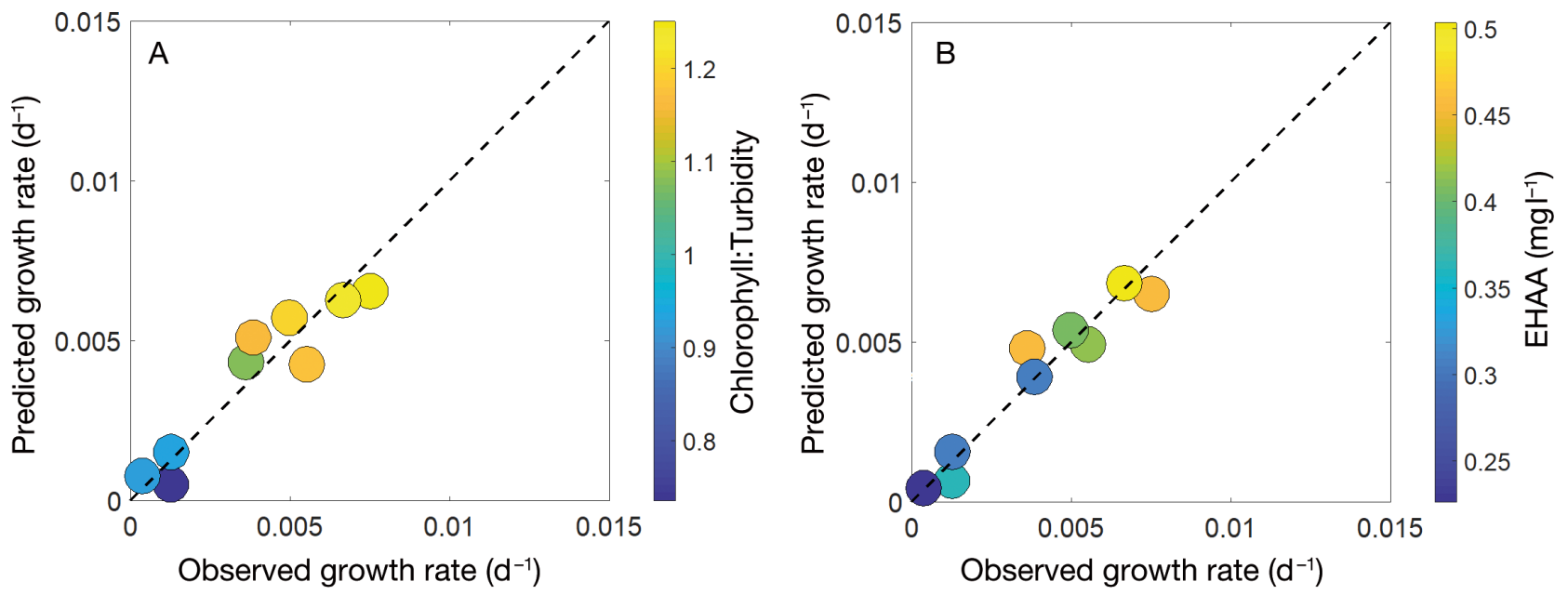

Fig. 6. Observed specific growth rate throughout summer versus predicted multiple linear regression models, constrained to 3 parameters, that model the same specific growth rate. (A) Optimal baseline model using high-density, oceanographic parameters from LOBO buoy. Color codes indicate role of chl a:Turbidity term. (B) Optimal model with the addition of EHAA shows improvement in model fit. Color codes indicate role of EHAA. In both models, 1 outlier point (30 June SGR measurements) has been eliminated. See Table 3 for equations and fitting statistics 
Indeed, particulate phytodetrital complexes observed by FlowCam under natural conditions were cleared from the water column by oysters. We estimated that, on average, oysters reduced the biovolume of phytodetritus by $83 \%$, suggesting that these complexes represent a significant supply of potentially bioavailable phytodetritus to oysters. Clearance rates (rate of removal of particles from the water column) measure only the initial feeding behavior. While clearance of a particle can lead to the assimilation of nutrients, it cannot establish the nutritional importance of cleared particles as they could also be rejected in pseudofeces. Nevertheless, clearance of phytodetritus is indicative of an in situ feeding capability that could nourish oysters and influence water clarity (Newell 2004).

Observation of high AE of EHAA in the seasonal field study could indicate utilization of detritus under natural field conditions. However, detrital abundance was low relative to the abundance of phytoplankton on both dates (EHAA:chl a ratios were 52 and $37 \mathrm{~g} \mathrm{EHAA}^{-1} \mathrm{chl} a$, such that the nearly complete absorption of labile proteins by oysters does not confirm absorption of detrital proteins. Unfortunately, insufficient biodeposits were obtained to estimate AE of EHAA earlier in the season when detrital abundance was higher (e.g. EHAA:chl a ratio was $174 \mathrm{~g} \mathrm{EHAA} \mathrm{g}^{-1} \mathrm{chl}$ a in May), so it is unclear if the high $\mathrm{AE}$ of EHAA observed during the September diatom bloom would apply when the seston is more detritus-rich.

\subsection{Detritus supplements oyster diets}

In the seasonal field study, we observed a significant correlation between EHAA concentrations and oyster growth. The baseline model using temperature, turbidity, chlorophyll- $\alpha$ fluorescence, and chlorophyll:turbidity ratio was powerful in predicting growth $\left(\mathrm{R}^{2}=0.84, \mathrm{AIC}=-13.54\right)$. Nevertheless, including EHAA improved fit of the model $\left(\mathrm{R}^{2}=0.91\right.$, $\mathrm{AIC}=-14.08$ ) and increased its significance from 0.01 to 0.0001 . The outlier (30 June) removed from both models was the highest growth rate of the season. While this growth spurt did not correlate with proteinaceous nutrition, it did correlate well with elevated ciliate abundance (data not shown). Ciliates likely did not provide bulk nutrition but may have stimulated oyster growth by providing trace nutrients such as lipids (Wikfors et al. 1996). Positive correlations between temperature and various metabolic rates (such as the growth rates measured here) are well established for $C$. virginica (Loosanoff \& Nomejko 1949, Ingle \& Dawson 1952, Dame 1972, Loosanoff 1958, Pernet et al. 2008, Lord \& Whitlatch 2014). The coefficient for chl a:Turb ratio is positive because chl a indicates food while turbidity indicates sediment resuspension that negatively affects feeding (see Fig. 4). Measuring EHAA provides important additional detail not captured by traditional measures of food quality, such as chl $a$, POM, and their derivative parameters of SELORG and REMORG. Because EHAA concentrations measure labile protein potentially available to oysters, and growth rates generally scale with EHAA concentration, our observations suggest that the supply of nutritional protein limits oyster growth.

The EHAA:chl a-derived estimates of detrital protein indicate a pool of bioavailable detrital protein that may contribute to meeting oysters' protein demands. These estimates resemble earlier measurements in the Damariscotta estuary (Laursen et al. 1996), albeit with different seasonal timing. We found

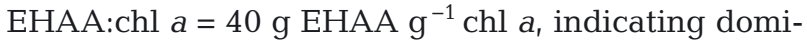
nance of EHAA by live phytoplankton, in a fall rather than spring bloom. The higher EHAA:chl a values, which indicate detrital EHAA, occurred in spring rather than late summer. Laursen et al. (1996) hypothesized a phytodetrital source of detrital proteins based on pigment-degradation products. In our study, FlowCam based measurements support this hypothesis, indicating that phytodetritus is a significant component of seston; the estimated biovolume of phytodetritus is on the same order of magnitude as diatoms.

Bioavailable phytodetrital protein thus appears to supplement oyster diets. Field-based analysis of the relative contributions of chlorophyll-rich SELORG and more detrital REMORG to oyster diets indicates that oysters need more organic material than can be gained by feeding on phytoplankton alone throughout most of the growing season, i.e. oysters required some amount of REMORG to complete their diets. During the majority of our seasonal field study, AR and AE were relatively high, even during periods when the concentration of REMORG exceeded that of SELORG. As noted above, however, AR decreased with increasing PIM:POM and became negative during a period of very high PIM:POM associated with sediment resuspension. Negative estimates of absorption rate may be due to metabolic fecal loss, described by Hawkins et al. (2013a) as representing losses of metabolically derived materials that have been ingested during feeding (i.e. ciliary mucus), excreted or sloughed into the alimentary canal, associated primarily with the extracellular processing of REMORG. Negative AR may be most evident when 
feeding upon diets that are rich in resuspended PIM (Urban \& Kirchman 1992, Hawkins et al. 1998, Strychar \& MacDonald 1999) which, in this estuary, is relatively poor in digestible protein (Anderson \& Mayer 1986). High PIM concentrations may also inhibit particle selection capabilities, thus exacerbating the food dilution effect (Kiørboe et al. 1981). Unseasonably high clearance rates were observed on this date, perhaps in response to moderately high seston concentration as previously reported for mussels (Hawkins et al. 1996), cockles (Iglesias et al. 1996) and oysters (Bayne 2017). C. virginica can reject inorganic matter and increase $C R$ in response to a decreasing fraction of organic matter (Galimany et al. 2017), as observed in this study.

Chlorophyll-rich SELORG could supply all measured POM uptake by oysters on only one date (27 September), when temperature and AR were both low and food was abundant. The necessary inclusion of detrital REMORG in oyster diets on all other sampling days is consistent with observations by Hawkins et al. (2013b) who reported a large role for REMORG in bivalve diets based on a C:chl a ratio of $12 \mathrm{~g} \mathrm{C} \mathrm{g}^{-1} \mathrm{chl} \mathrm{a}^{-1}$. Using the C:chl a ratio of 12 with our dataset resulted in REMORG providing the majority of organic material throughout the entire season. Our assumption of a C:chl a ratio of 50 is a more conservative assessment of the potential importance of detritus to oysters than previous studies (Hawkins et al. 2013a,b) and still demonstrates the requirement for REMORG in oyster diets in this study. Additionally, significant oyster growth coincided with the 3 occasions of particularly high REMORG contributions to diet (Fig. 2E).

The seasonal abundance of detrital protein and phytodetrital particles in the Damariscotta estuary, the oysters' need to absorb additional organic matter beyond phytoplankton to support growth, and the ability of oysters to feed on (field) and readily absorb (lab) phytodetritus together strongly implicate that phytodetrital proteins serve as a dietary component for $C$. virginica. Under protein-limited food regimes, the possible significance of phytodetrital proteins is enhanced. The POM concentration and organic content of seston in the Damariscotta estuary (mean: $1.75 \mathrm{mg} \mathrm{l}^{-1}$ POM and $21 \%$ organic content) are similar to other field studies of bivalve feeding under food-limiting conditions (Rheault \& Rice 1996, Gardner \& Thompson 2001, Penney et al. 2001). If Damariscotta estuary oysters are indeed protein-limited, they would be expected to assimilate any bioavailable proteins in the seston, including proteins from the observed labile detrital pool.
Intensive oyster culture can channel use of food resources in an estuarine ecosystem (e.g. Byron et al. 2011), and its impact may be explored as a carrying capacity. Our findings imply that food-based carrying capacity determinations for estuaries would benefit from measurements and analyses of EHAA, which provides a way to capture the additional nutrition that detritus provides in addition to live phytoplankton (measured by chlorophyll). This assay is not subject to the dominant and variable fraction of indigestible organic matter contained in the POM measure. The likely importance of detrital proteins in oyster diets at a highly successfully aquaculture site suggests that measurements such as EHAA would be useful to aquaculturists considering new sites as a method to characterize the full suite of bioavailable food resources available to oysters.

\section{CONCLUSIONS}

Assessing the abundance of 'detritus' and its contribution to Crassostrea virginica diets remains difficult. Detritus in the Damariscotta estuary contains a wide variety of products including algal necromass, heterotrophic biomass, and heterotrophic necromass. Our laboratory experiment shows that the nutritional potential of phytoplankton does not disappear with decay and that algal necromass complexes are readily absorbed by oysters. These findings are corroborated by field observations of oysters clearing phytodetritus. The seasonal field study shows that non-living and/or non-algal organic matter (as esti-

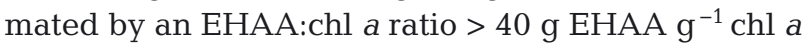
and high REMORG abundance) supports the nutrition and growth of oysters. Labile protein, which likely contains some detrital proteins, was absorbed very efficiently by oysters. EHAA measurements function well to explain variations in oyster growth, suggesting that Damariscotta estuary oysters may be, at least partially, growth-limited by protein availability. Protein limitation provides a biochemical reason why oysters might also clarify water columns of some kinds of detritus, refining our understanding of one of the ecological services provided by this species.

The EHAA procedure is a biomimetic chemical assay that has predictive power at the ecosystem level. It measures material often not assessed in the chl a measurement and yet is more focused than measurements of POM, and therefore provides independent environmental information and is a useful tool to estimate one fraction of the bioavailable pool of food, including detritus. 
In the highly successful aquaculture region of the upper Damariscotta estuary, detritus can provide bioavailable protein that contributes to oyster growth. Measuring bioavailable protein improves our understanding of the nutritional resources available to oysters beyond POM and chl a. Therefore, aquaculture expansions in new estuarine systems would benefit from considering non-phytoplanktonic protein sources. Directly measuring the biologically limiting component of growth, such as EHAA, may enable expansion into systems other than the Damariscotta estuary, which is necessary for the Maine oyster aquaculture industry to continue to grow.

Acknowledgements. We thank the Sustainable Ecological Aquaculture Network (SEANET) for funding the project (National Science Foundation Award \#11A-1355457). We are very thankful to the Maine Aquaculture Innovation Center (Orono, ME) for use of the biodeposition chambers. We thank Charlie Walsh at Maine Shellfish Developers (Darling Marine Center) for providing the Thalassiosira weissflogii culture. We acknowledge Laura Lubelczyk, Dr. Nicole Poulton, and Dr. Cynthia Heil for their work on the Seasonal Oyster Size Selectivity Project (SEANET mini-grant), from which selected data are presented here (FlowCam data of phytodetritus and diatom abundance and biovolume). Thank you to intern Antonia Barela, graduate student Kate Liberti, research specialist Kathleen Thornton, and boat captain Robbie Downs, who assisted with field and laboratory work. Dr. Anthony Hawkins was very helpful with advice regarding the biodeposition method and feeding rate calculations. We appreciate input from 3 anonymous reviewers and the editor, Brett Dumbauld, who provided thoughtful suggestions and improved this manuscript.

\section{LITERATURE CITED}

Alber M, Valiela I (1996) Utilization of microbial aggregates by bay scallop Argopecten irradians (Lamarck). J Exp Mar Biol Ecol 195:71-89

* Anderson E, Mayer LM (1986) The interaction of tidal currents on a disturbed intertidal bottom with a resulting change in particulate matter quantity, texture and food quality. Estuar Coast Shelf Sci 22:19-29

Barillé L, Prou J, Héral M, Razet D (1997) Effects of high natural seston concentration on the feeding, selection, and absorption of the oyster Crassostrea gigas (Thunberg). J Exp Mar Biol Ecol 212:149-172

Bayne BL (2009) Carbon and nitrogen relationships in the feeding and growth of the Pacific oyster Crassostrea gigas (Thunberg). J Exp Mar Biol Ecol 374:19-30

Bayne B (2017) Biology of oysters. Dev Aquacult Fish Sci, Vol 41. Academic Press, London

Biddanda BA, Pomeroy LR (1988) Microbial aggregation and degradation of phytoplankton-derived detritus in seawater. I. Microbial succession. Mar Ecol Prog Ser 42:79-88

Bonifácio P, Bourgeois S, Labrune C, Amouroux JM and others (2014) Spatiotemporal changes in surface sediment characteristics and benthic macrofaunal composition off the Rhône River in relation to its hydrological regime.
Estuar Coast Shelf Sci 151:196-209

* Bourlès Y, Alunno-Bruscia M, Pouvreau S, Tollu G and others (2009) Modelling growth and reproduction of the Pacific oyster Crassostrea gigas: advances in the oysterDEB model through application to a coastal pond. J Sea Res 62:62-71

* Bowen SH, Lutz EV, Ahlgren MO (1995) Dietary protein and energy as determinants of food quality: trophic strategies compared. Ecology 76:899-907

* Brown MR, Jeffrey SW, Volkman JK, Dunstan GA (1997) Nutritional properties of microalgae for mariculture. Aquaculture 151:315-331

Burger W, Burge MJ (2008) Digital image processing: an algorithmic introduction using Java. Springer, New York, NY

Burnham KP, Anderson DR (2002) Model selection and multimodel inference: a practical information-theoretic approach. Springer, New York, NY

Byron C, Link J, Costa-Pierce B, Bengtson D (2011) Calculating ecological carrying capacity of shellfish aquaculture using mass-balance modeling: Narragansett Bay, Rhode Island. Ecol Modell 222:1743-1755

Carriker MR, Gaffney PM (1996) A catalogue of selected species of living oysters (Ostreacea) of the world. In: Kennedy VS, Newell RIE, Eble AF (eds) The eastern oyster: Crassostrea virginica. Maryland Sea Grant, College Park, MD

* Cebrian J, Lartigue J (2004) Patterns of herbivory and decomposition in aquatic and terrestrial ecosystems. Ecol Monogr 74:237-259

* Cetinić I, Perry MJ, D'Asaro E, Briggs N, Poulton N, Sieracki ME, Lee CM (2015) Optical community index to assess spatial patchiness during the 2008 North Atlantic bloom. Biogeosciences 12:2179-2194

* Chang F, Chen CJ, Lu CJ (2004) A linear-time componentlabeling algorithm using contour tracing technique. Comput Vis Image Underst 93:206-220

* Chi SY, Zhou QC, Tan BP, Dong XH, Yang QH, Zhou JB (2010) Effects of dietary protein and lipid levels on growth performance, carcass composition, and digestive enzyme of the juvenile spotted babylon, Babylonia areaolata Link 1807. J World Aquacult Soc 41:903-911

Clausen I, Riisgård HU (1996) Growth, filtration and respiration in the blue mussel Mytilus edulis: no evidence for physiological regulation of the filter-pump to nutritional needs. Mar Ecol Prog Ser 141:37-45

* Comeau LA (2014) Spring awakening temperature and survival of sediment-covered oysters Crassostrea virginica. Aquaculture 430:188-194

* Costa-Pierce BA (2010) Sustainable ecological aquaculture systems: the need for a new social contract for aquaculture development. Mar Technol Soc J 44:88-112

* Crosby MP, Newell RIE, Langdon CJ (1990) Bacterial mediation in the utilization of carbon and nitrogen from detrital complexes by Crassostrea virginica. Limnol Oceanogr 35:625-639

Dame RF (1972) The ecological energies of growth, respiration and assimilation in the intertidal American oyster Crassostrea virginica. Mar Biol 17:243-250

* Dauwe B, Middleburg JJ, Rijswijk PV, Sinke J, Herman PMJ, Heip CHR (1999) Enzymatically hydrolyzable amino acids in North Sea sediments and their possible implications for sediment nutritional values. J Mar Res 57:109-134

Galimany E, Lunt J, Freeman CJ, Reed S, Segura-García I, Paul VJ (2017) Feeding behavior of eastern oysters Crass- 
ostrea virginica and hard clams Mercenaria mercenaria in shallow estuaries. Mar Ecol Prog Ser 567:125-137

Gardner JPA, Thompson RJ (2001) Naturally low seston concentration and the net energy balance of the greenshell mussel (Perna canaliculus) at Island Bay, Cook Strait, New Zealand. N Z J Mar Freshw Res 35:457-468

* Grémare A, Amouroux JM, Charles F, Dinet A and others (1997) Temporal changes in the biochemical composition and nutritional value of the particulate organic matter available to surface deposit-feeders: a two year study. Mar Ecol Prog Ser 150:195-206

Hager SW, Harmon DD, Alpine AE (1984) Chemical determination of particulate nitrogen in San Francisco Bay: nitrogen:chlorophyll a ratios in plankton. Estuar Coast Shelf Sci 19:193-204

Hawkins AJS, Bayne BL (1991) Nutrition of marine mussels: factors influencing relative utilization of protein and energy. Aquaculture 94:177-196

Hawkins AJS, Bayne BL, Mantoura RFC, Llewellyn CA, Navarro E (1986) Chlorophyll degradation and absorption throughout the digestive system of the blue mussel, Mytilus edulis L. J Exp Mar Biol Ecol 96:213-223

* Hawkins AJS, Smith RFM, Bayne BL, Héral M (1996) Novel observations underlying the fast growth of suspensionfeeding shellfish in turbid environments: Mytilus edulis. Mar Ecol Prog Ser 131:179-190

* Hawkins AJS, Bayne BL, Bougrier S, Héral M and others (1998) Some general relationships in comparing the feeding physiology of suspension-feeding bivalve molluscs. J Exp Mar Biol Ecol 219:87-103

Hawkins AJS, Pascoe PL, Parry H, Brinsley M and others (2013a) Shellsim: a generic model of growth and environmental effects validated across contrasting habitats in bivalve shellfish. J Shellfish Res 32:237-253

* Hawkins AJS, Pascoe PL, Parry H, Brinsley M and others (2013b) Comparative feeding on chlorophyll-rich versus remaining organic matter in bivalve shellfish. J Shellfish Res 32:883-897

Holm-Hansen O, Riemann B (1978) Chlorophyll a determination: improvements in methodology. Oikos 30:438-447

Ibarrola I, Iglesias JIP, Navarro E (1996) Differential absorption of biochemical components in the diet of the cockle Cerastoderma edule: enzymatical responses to variations in seston composition. Can J Zool 74:1887-1897

Ibarrola I, Navarro E, Iglesias JIP, Urrutia MB (2000) Temporal changes of feeding and absorption of biochemical components in Cerastoderma edule fed an algal diet. J Mar Biol Assoc UK 80:119-125

Iglesias JIP, Urrutia MB, Navarro E, Alvarez-Jorna P, Larretxea X, Bougrier S, Heral M (1996) Variability of feeding processes in the cockle Cerastoderma edule (L.) in response to changes in seston concentration and composition. J Exp Mar Biol Ecol 197:121-143

Iglesias JIP, Urrutia MB, Navarro E, Ibarrola I (1998) Measuring feeding and absorption in suspension-feeding bivalves: an appraisal of the biodeposition method. J Exp Mar Biol Ecol 219:71-86

Ingersoll E (1881) The oyster industry. In: Baird SF, Goode GB (eds) The history and present condition of the fishery industries. Tenth Census of the United States, Dept Interior, Government Printing Office, Washington, DC

Ingle RM, Dawson CE (1952) Growth of the American oyster Crassostrea virginica (Gmelin) in Florida Waters. Bull Mar Sci Gulf Caribb 2:393-404

Karayücel S, Çelik MY, Karayücel İ, Erik G (2010) Growth and production of raft cultivated Mediterranean mussels (Mytilus galloprovincialis Lamarck, 1819) in Sinop, Black Sea. Turk J Fish Aquat Sci 10:9-17

K Kiørboe T, Møhlenberg F, Nøhr O (1981) Effect of suspended bottom material on growth and energetics in Mytilus edulis. Mar Biol 61:283-288

KKreeger DA, Langdon CJ (1993) Effect of dietary protein content on juvenile mussels Mytilus trossulus. Biol Bull 185:123-139

* Langdon CJ, Newell RIE (1990) Utilization of detritus and bacteria as a food source by two bivalve suspensionfeeders, the oyster Crassostrea virginica and the mussel Geukensia demissa. Mar Ecol Prog Ser 58:299-310

* Laursen AK, Mayer LM, Townsend DW (1996) Lability of proteinaceous material in estuarine seston and subcellular fractions of phytoplankton. Mar Ecol Prog Ser 136:227-234

* Levinton JS, Ward JE, Shumway SE (2002) Feeding responses of the bivalve Crassostrea gigas and Mytilus trossulus to chemical composition of fresh and aged kelp detritus. Mar Biol 141:367-376

Loosanoff VL (1958) Some aspects of feeding behavior of oysters at different temperatures. Biol Bull 114:57-70

Loosanoff VL (1962) Effects of turbidity on some larval and adult bivalves. Proc Gulf Caribb Fish Inst 14:80-95

Loosanoff VL, Nomejko CA (1949) Growth of oysters, O. virginica, during different months. Biol Bull 97:82-94

KLoosanoff VL, Tommers FD (1948) Effect of suspended silt and other substances on rate of feeding of oysters. Science 107:69-70

Lopez GR, Levinton JS (2011) Particulate organic detritus and detritus feeders in coastal food webs. In: Wolanski E, McLusky DS (eds) Treatise on estuarine and coastal science, Vol 6. Academic Press, Waltham, p 5-21

* Lord J, Whitlatch R (2014) Latitudinal patterns of shell thickness and metabolism in the eastern oyster Crassostrea virginica along the east coast of North America. Mar Biol 161:1487-1497

MacDonald BA, Ward JE (1994) Variation in food quality and particle selectivity in the sea scallop Placopecten magellanicus (Mollusca: Bivalvia). Mar Ecol Prog Ser 108:251-264

Maine Department of Marine Resources (2018) Maine Aquaculture Harvest Data. www.maine.gov/dmr/aquaculture/ harvestdata/index.html (accessed 15 Sep 2019)

*Malkin SY, Silsbe GM, Smith REH, Howell ET (2012) A deep chlorophyll maximum nourishes benthic filter feeders in the coastal zone of a large clear lake. Limnol Oceanogr 57:735-748

Mayer LM, Schick LL, Sawyer T, Plante CJ, Jumars PA, Self RL, (1995) Bioavailable amino acids in sediments: a biomimetic, kinetics-based approach. Limnol Oceanogr 40:511-520

Mayer LM, Townsend DW, Pettigrew NR, Loder TC and others (1996) The Kennebec, Sheepscot, and Damariscotta Estuaries: seasonal oceanographic data. Tech Rep No. 9601, University of Maine, Orono, ME

* Mayer LM, Schick LL, Hardy KR, Estapa ML (2009) Photodissolution and other photochemical changes upon irradiation of algal detritus. Limnol Oceanogr 54:1688-1698

McAlice BJ (1977) A preliminary oceanographic survey of the Damariscotta River estuary, Lincoln County, Maine. Maine Sea Grant TR-13-77, Orono, ME

*Menden-Deuer S, Lessard EJ (2000) Carbon to volume relationships for dinoflagellates, diatoms, and other protist plankton. Limnol Oceanogr 45:569-579 
Mills D (2000) Combined effects of temperature and algal concentration on survival, growth and feeding physiology of Pictada maxima (Jameson) spat. J Shellfish Res 19: 159-166

Navarro E, Iglesias JIP, Ortega MM (1992) Natural sediment as a food source for the cockle Cerastoderma edule (L.): effect of variable particle concentration on feeding, digestion, and the scope for growth. J Exp Mar Biol Ecol 156: 69-87

Navarro E, Méndez S, Ibarrola I, Urrutia MB (2009) Comparative utilization of phytoplankton and vascular plant detritus by the cockle Cerastoderm edule: digestive responses during diet acclimation. Aquat Biol 6:247-262

* Navarro E, Méndez S, Urrutia MB, Arambalza U, Ibarrola I (2016) Digestive selection underlies differential utilization of phytoplankton and sedimentary organics by infaunal bivalves: experiments with cockles (Cerastoderma edule) using cross-labelled mixed diets. Mar Environ Res 120:111-121

Nelson TC (1960) The feeding mechanism of the oyster. II. On the gills and palps of Ostrea edulis, Crassostrea virginica, and C. angulata. J Morphol 107:163-203

Newell RC (1982) The energetics of detritus utilization in coastal lagoons and nearshore waters. Oceanol Acta 1: 355-377

Newell RIE (2004) Ecosystem influences of natural and cultivated populations of suspension-feeding bivalve molluscs: a review. J Shellfish Res 23:51-61

Newell RIE, Jordan SJ (1983) Preferential ingestion of organic material by the American oyster Crassostrea virginica. Mar Ecol Prog Ser 13:47-53

Newell RIE, Langdon CJ (1986) Digestion and absorption of refractory carbon from the plant Spartina alterniflora by the oyster Crassostrea virginica. Mar Ecol Prog Ser 34: 105-115

Newell RC, Lucas MI, Linley EAS (1981) Rate of degradation and efficiency of conversion of phytoplankton debris by marine micro-organisms. Mar Ecol Prog Ser 6:123-136

Paerl HW (1984) Alteration of microbial metabolic activities in association with detritus. Bull Mar Sci 35:393-408

Palmer RE, Williams LG (1980) Effects of particle concentration on filtration efficiency of the bay scallop Argopecten irradians and the oyster Crassostrea virginica. Ophelia 19:163-174

* Penney RW, McKenzie CH, Mills TJ (2001) Assessment of the particulate food supply available for mussel (Mytilus spp.) farming in a semi-enclosed, Northern Inlet. Estuar Coast Shelf Sci 53:107-121

Pernet F, Tremblay R, Redjah I, Sévigny JM, Gionet C (2008) Physiological and biochemical traits correlate with differences in growth rate and temperature adaptation among groups of the eastern oyster Crassostrea virginica. J Exp Biol 211:969-977

Ren JS, Ross AH (2001) A dynamic energy budget model of the Pacific oyster Crassostrea gigas. Ecol Modell 142:105-120

Rheault RB, Rice MA (1996) Food-limited growth and condition index in the eastern oyster, Crassostrea virginica (Gmelin 1791), and the bay scallop, Argopecten irradians irradians (Lamarck 1819). J Shellfish Res 15:271-283

Rice DL, Hanson RB (1988) A kinetic model for detritus nitrogen: role of the associated bacteria in nitrogen accumulation. Bull Mar Sci 35:326-340

Riisgård HU, Lundgreen K, Larsen PS (2012) Field data and

Editorial responsibility: Brett Dumbauld,

Newport, Oregon, USA growth model for mussels Mytilus edulis in Danish waters. Mar Biol Res 8:683-700

Roman MR (1983) Nitrogenous nutrition of marine heterotrophs. In: Carpenter EJ, Capone DG (eds) Nitrogen in the marine environment. Academic Press, London, p 347-384

* Romberger HP, Epifanio CE (1981) Comparative effects of diets consisting of one or two algal species on assimilation efficiencies and growth of juvenile oysters, Crassostrea virginica (Gmelin). Aquaculture 25:77-87

Kanzone DM, Tank JL, Meyer JL, Mulholland PJ, Findlay SEG (2001) Microbial incorporation of nitrogen in stream detritus. Hydrobiologia 464:27-35

'Sieracki ME, Reichenbach SE, Webb KL (1989) Evaluation of automated threshold selection methods for accurately sizing microscopic fluorescent cells by image analysis. Appl Environ Microbiol 55:2762-2772

Sikder S, Mukherjee I, Panja SC, Bera S (2014) A Mahalanobis Taguchi system-based approach for correlated multiple response process monitoring. Proc Int Conf Ind Eng Oper Manag, Bali, 7-9 Jan 2014, p 2118-2125

K Soletchnik P, Goulletquer P, Héral M, Razet D, Geairon P (1996) Evaluation du bilan énergétique del'huître creuse, Crassostrea gigas, en baie de Marennes-Oléron (France). Aquat Living Resour 9:65-73

Steinberg DK, Saba GK (2008) Nitrogen consumption and metabolism in marine zooplankton. In: Capone EJ, Douglas DG (eds) Nitrogen in the marine environment. Academic Press, London, p 1135-1193

Strychar KB, MacDonald BA (1999) Impact of suspended peat particles on feeding and absorption rates in cultured eastern oysters (Crassostrea virginica Gmelin). J Shellfish Res 18:437-444

Suplicy FM, Schmitt JF, Moltschaniwskyj NA, Ferreira JF (2003) Modeling of filter-feeling behavior in the brown mussel, Perna perna (L.), exposed to natural variations of seston availability in Santa Catarina, Brazil. J Shellfish Res 22:125-134

*Taylor AH, Geider RJ, Gilbert FJH (1997) Seasonal and latitudinal dependencies of phytoplankton carbon-tochlorophyll a ratios: results of a modelling study. Mar Ecol Prog Ser 152:51-66

*Urban ER Jr, Kirchman DL (1992) Effect of kaolinite clay on the feeding activity of the eastern oyster Crassostrea virginica (Gmelin). J Exp Mar Biol Ecol 160:47-60

Urrutia MB, Iglesias JIP, Navarro E, Prou J (1996) Feeding and absorption in Cerastoderma edule under environmental conditions in the Bay of Marennes-Oleron (Western France). J Mar Biol Assoc UK 76:431-450

*Ward EJ, Shumway SE (2004) Separating the grain from the chaff: particle selection in suspension- and deposit-feeding bivalves. J Exp Mar Biol Ecol 300:83-130

*Ward EJ, Levinton JS, Shumway SE, Cucci T (1998) Particle selection in bivalves: in vivo determination of the pallial organs of selection. Mar Biol 131:283-292

* Welschmeyer NA, Lorenzen CT (1984) Carbon-14 labeling of phytoplankton carbon and chlorophyll a carbon: determination of specific growth rates. Limnol Oceanogr 29: 135-145

WWikfors GH, Patterson GW, Ghosh P, Lewin RA, Smith BC, Alix JH (1996) Growth of post-set oysters, Crassostrea virginica, on high-lipid strains of algal flagellates Tetraselmis spp. Aquaculture 143:411-419

Submitted: February 25, 2019; Accepted: August 4, 2019 Proofs received from author(s): September 15, 2019 